\title{
Traumatic Brain Injury Caused by Motor Vehicle Collision and Alcoholism in Piauí
}

\section{Traumatismo Cranioencefálico por Colisão Automobilística e Alcoolismo no Piauí}

\author{
Benjamim Pessoa Vale ${ }^{1,2}$ Juçara Gonçalves de Castro ${ }^{3}$ Marx Lima Barros Araújo ${ }^{1}$ \\ Herb Barrêto de Morais ${ }^{3}$ Lívio Pereira de Macêdo ${ }^{4}$
}

${ }^{1}$ Instituto de Neurociências, Teresina, PI, Brazil

2 Sociedade Brasileira de Neurocirurgia, São Paulo, SP, Brazil

${ }^{3}$ Faculdade Integral Diferencial, Teresina, PI, Brazil

${ }^{4}$ Hospital da Restauração, Recife, PE, Brazil

Address for correspondence Lívio Pereira de Macêdo, Rua João Fernandes Vieira, 540, Boa Vista, Recife, PE, Brazil CEP: 50050-245 (e-mail: livio21@gmail.com).

Arq Bras Neurocir 2018;37:174-181.

\begin{abstract}
Keywords

- craniocerebral trauma

- diffuse axonal injury

- alcoholism

- traffic accidents
\end{abstract}

Resumo
Objectives To determine the relationship between alcohol consumption and the incidence of traumatic brain injury (TBI) with diffuse axonal injury (DAI), determining these indices, checking acquired comorbidities and characterizing the patients by gender, age and race/color, as well as describing the characteristics of the motor vehicle collision (vehicle, period of the day, day of the week and site) in people admitted to an emergency hospital in the city of Teresina, in the state of Piauí, Brazil.

Methods We have analyzed the data contained in the medical records of patients admitted with a history of motor vehicle collision and severe TBI in intensive care units, based on the forms provided by the Mobile Emergency Care Service (SAMU, in the Portuguese acronym) in the period between February 28 and November 28, 2013.

Results In the period covered by the present study, 200 individuals were analyzed, and 54 (27\%) had consumed alcohol; of these 11 had DAI. Of the total sample, 17\% (34) presented DAI, however, with unknown data regarding the consumption of alcoholic beverages.

Conclusion Considering the data, we observed that the profile of the head trauma patients are brown men, mostly (53.5\%) aged between 15 and 30 years. The collisions occurred mostly on weekends and at night (55\%), and $89.5 \%$ of the crashes involved motorcycles.

Objetivos Determinar a relação entre a ingestão de bebidas alcoólicas e a incidência de traumatismo cranioencefálico (TCE) grave com lesão axonal difusa (LAD), determinando estes índices, verificando comorbidades adquiridas, e caracterizando os pacientes segundo gênero, idade e raça/cor, além de descrever as características da colisão automobilística (veículo, turno, dia da semana e local), em pessoas admitidas em um hospital de urgência de Teresina, Piauí. received

January 11, 2016

accepted

April 6, 2016

published online

May 23, 2016
DOI https://doi.org/

$10.1055 / \mathrm{s}-0036-1583935$.

ISSN 0103-5355.
Copyright (e) 2018 by Thieme Revinter

Publicações Ltda, Rio de Janeiro, Brazil

License terms

(c) $9 \ominus \$$ 
Métodos Foram analisados dados contidos em prontuários de pacientes admitidos com histórico de colisão automobilística e TCE grave em unidades de terapia intensiva, e baseados na ficha do Serviço de Atendimento Móvel de Urgência (Samu), no período de 28 de fevereiro a 28 de novembro de 2013.

Resultados No período da pesquisa, foram analisados 200 indivíduos, dos quais 54 (27\%) haviam ingerido bebidas alcoólicas; destes, 11 apresentavam LAD. Em 17\% (34)

\section{Palavras-Chave}

- traumatismos craniocerebrais

- lesão axonal difusa

- alcoolismo

- acidentes de trânsito da amostra havia a presença de LAD, no entanto, com dados ignorados a respeito da ingestão de bebidas alcoólicas.

Conclusão Considerando-se os dados, observou-se que o perfil do paciente vítima de traumatismo craniano é de homens pardos, com a maioria (53,5\%) na faixa etária entre 15 e 30 anos de idade. As colisões ocorreram em sua maioria aos finais de semana e durante a noite (55\%), e 89,5\% envolveram motocicletas.

\section{Introduction}

Trauma is defined as any harmful event that results from the release of specific forms of energy. Trauma is considered the leading cause of death in people aged between 1 and 44 years. Previously, unintentional trauma was called an accident, but today it is not the most appropriate term to define unintentional injuries from motor vehicle collisions. Emergency medical services prefer the term collision between motor vehicles because the term accident suggests that a person has suffered an injury as a result of fate, bad luck or divine intervention, which implies that the lesion was random and, therefore, unavoidable. ${ }^{1,2}$

In the case of driving under the influence of alcohol, the term accident loses its meaning even more, in view of the possibility of the drunk driver or motorcycle rider taking responsibility for injuring himself or others while driving the vehicle.

It is estimated that the incidence of head injuries in Brazil varies from 26.2 to 39.3 per 100 thousand inhabitants, with a mortality rate of $33.3 \%$ for severe traumatic brain injury (TBI). Such traumatic lesions in the central nervous system occur in all age groups, being more common in young adults between 15 and 24 years old, and it is among the individuals of this age group that the highest consumption of alcoholic beverages is observed in most countries, being one of the main factors responsible for the high incidence of traumatic events with victims. 3,4

Among those who survive traffic collisions, a high number of comorbidities is observed. These result from the direct impact or the effect of acceleration/deceleration, also called inertial effect, causing injuries by shearing, which may result in fragmentation of nerve fibers and perforation of vessels. ${ }^{5}$

This involvement of neuronal cells is synthesized by the term diffuse axonal injury (DAI), which is related to an immediate loss of consciousness as a consequence of the dysfunction of the reticular substance. Diffuse axonal injury is considered the most important sole cause of persistent disability following TBI. ${ }^{6}$

In the state of Piauí, according to data from the Independent Traffic Patrol Company (Ciptran, in the Portuguese acronym), most of the collisions recorded in April 2012 involved adults between 30 and 59 years old, the majority of which were male. In this same period, in the city of Teresina, there were 224 traumatic episodes with victims, with 5 fatal episodes, and 349 collisions without victims, in a total of 573 occurrences.

Given these data, it is possible that alcoholism is a determining factor in the occurrence of severe TBI due to traumatic episodes in traffic.

\section{Objectives}

The objective of the present study was to determine the relationship between alcoholic beverage consumption and the incidence of severe TBI with DAI in motor vehicle collisions in Piauí, in order to verify the acquired comorbidities, trace the profile of the patients according to gender, age and race/color, and describe the characteristics of the collision (vehicle, period of the day, day of the week and site).

\section{Methods}

The present research complied with the norms established by Resolution 466/12 of the Brazilian National Health Council (CNS, in the Portuguese acronym), whose function is to direct research involving human subjects.

After the approval of the research by the Plataforma Brasil database, the Ethics in Research Committee of Faculdade Integral Diferencial (CEP/Facid, in the Portuguese acronym) and the hospital in question (by signing the Term of Faithful Fiduciary), the present study was initiated on February 28, 2013.

The present study, characterized as a descriptive epidemiological exploratory study, was performed by reviewing medical charts of general and neurological intensive care units (ICUs), emergency rooms, semi-intensive care units and postoperative observation rooms of the emergency public hospital of the city of Teresina.

The present research covers epidemiology, prevention, education and control of human hospital infections. To carry out the study, the files of the Mobile Emergency Care Service 
(SAMU, in the Portuguese acronym) were used, from which the information contained in the charts of the patients was obtained, such as age, gender, tomographic evaluation of the head, site of the traumatic event, period of the day and date, means of locomotion of the victim, and ingestion of alcoholic beverages.

The present study included patients admitted to the aforementioned units of the hospital due to collisions between motor vehicles, resulting in severe TBI, with diagnosis confirmed by medical and radiological evaluation. The data ignored in the SAMU record, which would characterize the exclusion of the participants from the survey, were recorded to enable the discussion about the quality of the information in the medical records. The data was organized into forms.

The sample, therefore, was random or non-probabilistic, and was collected weekly. The data obtained with the variables contained in the chart were analyzed and converted into graphs and tables, to better present the results, using the program OriginPro 7.0 (OriginLab, Northampton, MA, US).

\section{Results}

In the period between February 28 and November 28, 2013, 200 medical records of patients admitted to a public hospital in Teresina with a history of motor vehicle collision and severe TBI were analyzed.

Regarding the profile of the collision victims analyzed in the period of the survey, $94.5 \%$ were male, and $5.5 \%$ were female (-Fig. 1); $1.5 \%$ were $\leq 14$ years old; $53.5 \%$ were aged between 15 and 30 years; 32\% were aged between 31 and 46 years; $7.5 \%$ were aged between 47 and 62 years; and $5 \%$ were aged between 63 and 78 years; there was $0.5 \%$ of ignored data (-Fig. 2). Regarding race/color, we observed that $24.5 \%$ were white; $47 \%$, brown-skinned; $24 \%$, black; and $4.5 \%$ of the SAMU files did not contain such data (-Fig. 3 ).

Regarding the characteristics of the collision, a higher index was observed at night (55\%), followed by the afternoon (20.5\%) and the morning (19\%). Of the medical records, 5.5\% did not contain this information (-Fig. 4). The morning period was considered as the hours between $6 \mathrm{Am}$ and 11:59 Aм; the afternoon, between 12 PM and 5:59 PM; and the night period, including the early morning, between 6:00 PM and 5:59 AM.

As for the day of the week, there was an increase in cases at the end of the week, with the number of cases remaining almost constant from Tuesday to Thursday (-Fig. 5).

Considering the means of locomotion, $89.5 \%$ were collisions involving motorcycles; $2.5 \%$ involved cars; $5.5 \%$ involved pedestrians; $2 \%$ involved bicycles; and $0.5 \%$ of the data was not available (-Fig. 6).

Regarding DAI, of the 45 (22,5\%) patients presenting severe DAI, only 11 had a record of alcohol ingestion. For the other 34, this data was unknown. Of the total patients analyzed in the medical records, 54 (27\%) had a record of alcohol ingestion, and only 11 of these (20.3\%) presented DAI; of the $77,5 \%$ who did not present DAI, $5,5 \%$ ingested

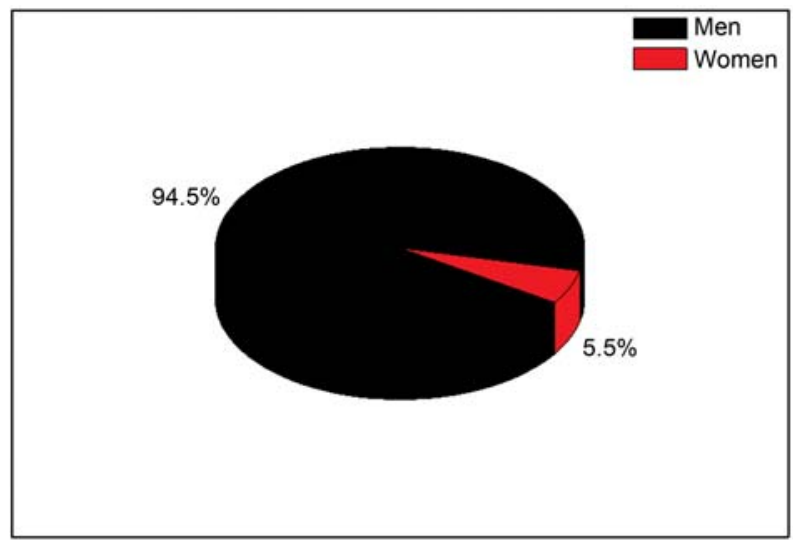

Fig. 1 Individuals with motor vehicle collision trauma treated at an emergency hospital in Teresina, in the state of Piauí, according to gender (February-November 2013).

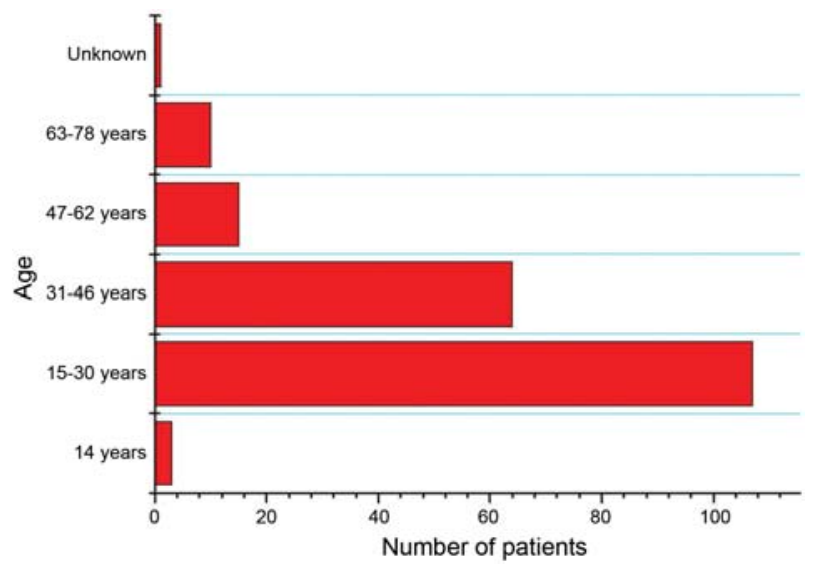

Fig. 2 Individuals with trauma from motor vehicle collision treated at an emergency hospital in Teresina, in the state of Piauí, according to age group (February-November 2013).

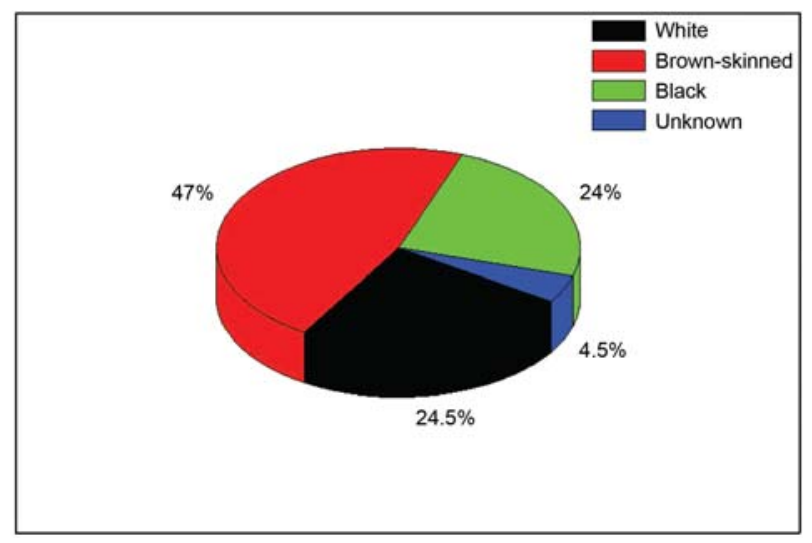

Fig. 3 Individuals with trauma from motor vehicle collision treated at an emergency hospital in Teresina, in the state of Piauí, according to race/color (February-November 2013). 


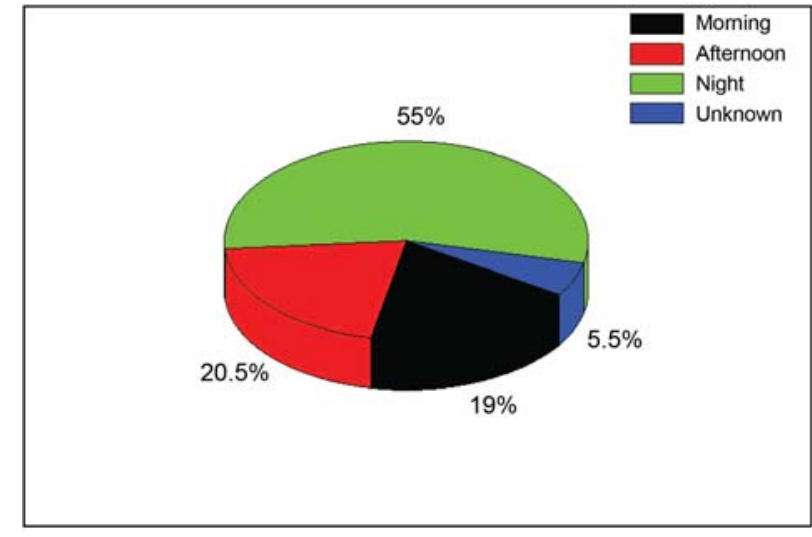

Fig. 4 Individuals with trauma from motor vehicle collision treated at an emergency hospital in Teresina, in the state of Piauí, according to the time of day (February-November 2013).



Fig. 5 Individuals with trauma from motor vehicle collision treated at an emergency hospital in Teresina, in the state of Piauí, according to the day of the week (February-November 2013).

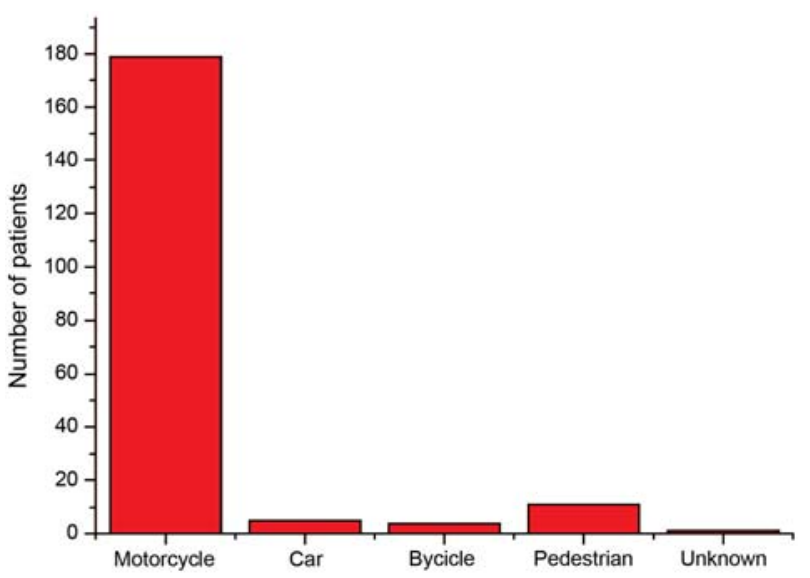

Fig. 6 Individuals with trauma from motor vehicle collision treated at an emergency hospital in Teresina, in the state of Piauí, according to the means of locomotion (February-November 2013).

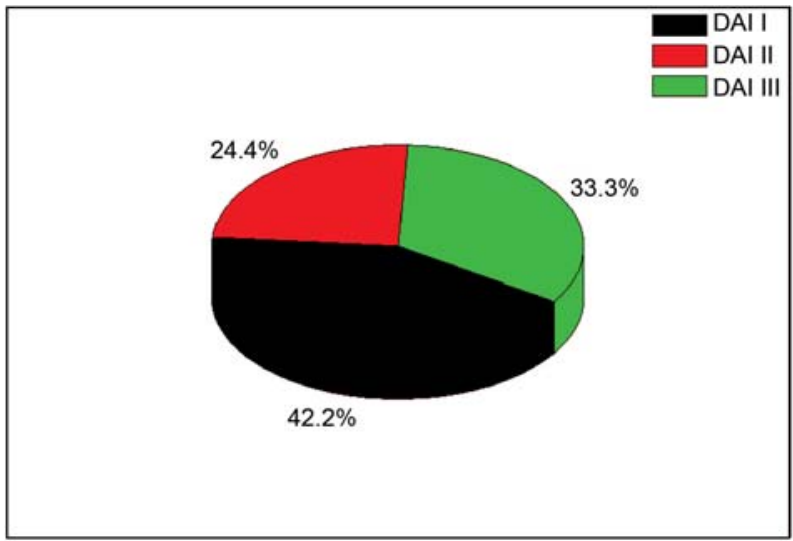

Fig. 7 Individuals with trauma from motor vehicle collision treated at an emergency hospital in Teresina, in the state of Piauí, with diagnosis of diffuse axonal injury (DAI) (February-November 2013).

alcohol, and the record of this variable was not available for the rest of patients. Therefore, there was no statistical significance in the correlation between the severe TBI index and alcohol ingestion.

Considering the types of DAI ( - Fig. 7 ), of the 45 patients who were diagnosed with this lesion, $42.2 \%$ (19) were DAI grade I; $24.4 \%$ (11), grade II; and 33.3\% (15), grade III. DAI can be classified in these three grades ( - Table 1 ).

It was also possible to observe other criteria of severity other than DAI (although it was not the objective of the present study), registered in the form as the "other lesions" variable. Most of those were related to extradural hematoma, subdural hematoma, intracranial hypertension following the hematoma, cerebral edema, pneumocephalus, and Glasgow coma scale $<10$.

In addition to the neurological lesions, there were also fractures consequent to polytrauma caused by accidents, mainly those involving motorcycles, such as fracture of the face bones, thoracic and abdominal hemorrhages, mainly in the region of the head (blepharoplasty hematoma, otorrhagia), and spinal cord trauma, which also determine a worse prognosis and higher morbidity and mortality in these individuals.

As for the city, the traffic collisions evaluated were distributed across the states of Piauí and Maranhão (-Figs. 8 and $\mathbf{9}$ ). The cities in Piauí, with the exception of the capital Teresina, and in Maranhão, together account for $81 \%$ of the demand at

Table 1 Graduation of the diffuse axonal injury according to Hortobágyi and Al-Sarraj (2008) ${ }^{7}$

\begin{tabular}{|l|l|l|l|}
\hline & $\begin{array}{l}\text { Diffuse } \\
\text { axonal } \\
\text { injury }\end{array}$ & $\begin{array}{l}\text { Corpus } \\
\text { callosum } \\
\text { hemorrhage }\end{array}$ & $\begin{array}{l}\text { Lesion in } \\
\text { DLBS and } \\
\text { RBS }\end{array}$ \\
\hline Grade I & Present & Absent & Absent \\
\hline Grade II & Present & Present & Absent \\
\hline Grade III & Present & Present & Present \\
\hline
\end{tabular}

Abbreviations: DLBS, dorsolateral region of the brainstem; RBS, rostral region of the brainstem. 


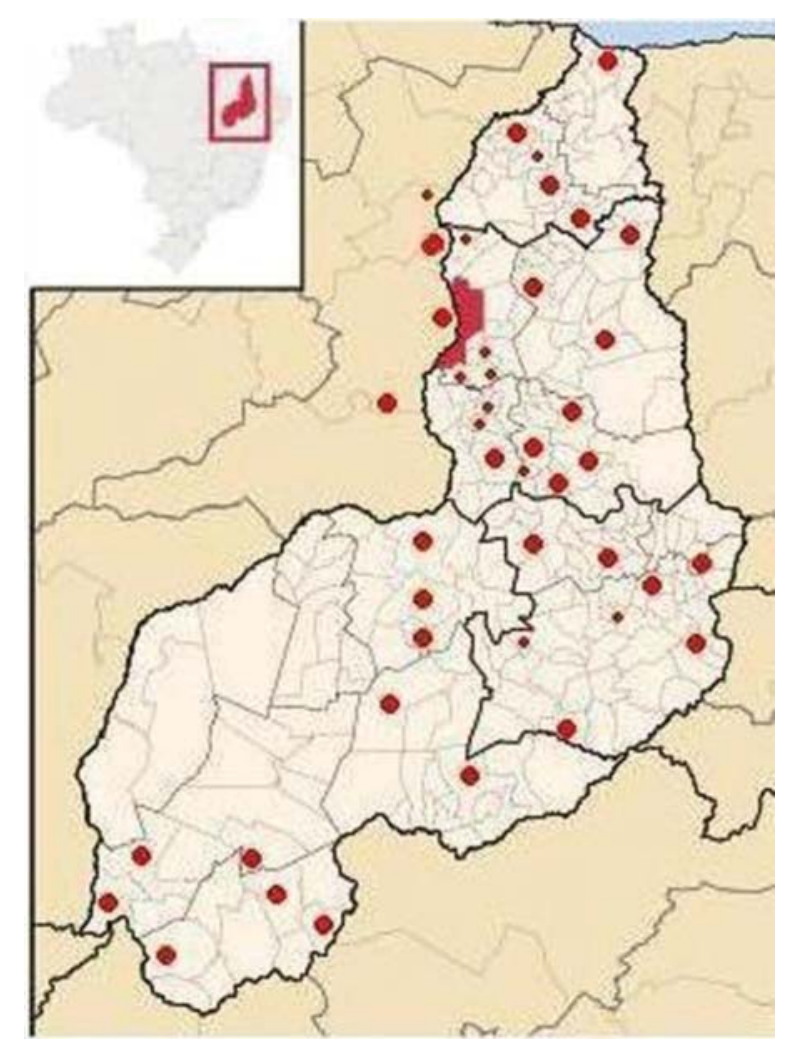

Fig. 8 Map of the cities of origin of the victims of motor vehicle collisions treated at an emergency hospital in Teresina, in the state of Piauí. the emergency service, being Timon do Maranhão ( 5 km away from Teresina) and Lagoa do Piauí (40 km away from Teresina) the nearest, and Corrente ( $874 \mathrm{~km}$ away from Teresina), the farthest.

\section{Discussion}

The majority of the victims (94.5\%) who composed the sample were male, thus representing the main victims of motor vehicle collisions with severe TBI. These data are similar to those found in another study in the Teresina emergency public service, in which most victims were also men, and accounted for $85.8 \%$ of cases. ${ }^{8}$

These data are also in line with the a study conducted in the city of Tubarão, in the state of Santa Catarina, which outlined the epidemiological profile of the victims of traffic collisions treated at the emergency service of Hospital Nossa Senhora da Conceição, $78.2 \%$ of which were male. ${ }^{9}$

Similar data were also found in another study performed in an emergency service in Piauí, which showed a predominance of male patients (84\%) in trauma care, and a similar study in the city of Londrina, in which most victims of traffic collisions were male, with values ranging from $72.4 \%$ in 1998 to $75.2 \%$ in $2000 .^{8,10}$

Regarding the age group, the data of the young adults characterized in this study was similar to those of a previous study performed by Santos et $\mathrm{al}^{11}$ in an emergency service, whose age group was mainly between 15 and 24 years old

\begin{tabular}{|c|c|c|}
\hline City & Distance to capital & Number of victims \\
\hline Teresina & 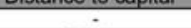 & 38 \\
\hline Floriano & $240 \mathrm{Km}$ & 14 \\
\hline Uniảo & $59 \mathrm{Km}$ & 10 \\
\hline Piripiri & $160 \mathrm{Km}$ & 9 \\
\hline Timon - MA & $\begin{array}{l}450 \mathrm{Km} \text { to Săo Luis } \\
5 \mathrm{Km} \text { to Teresina }\end{array}$ & 7 \\
\hline Campo Maior & $84 \mathrm{Km}$ & 6 \\
\hline Pedroll & $210 \mathrm{Km}$ & 5 \\
\hline Picos & $307 \mathrm{Km}$ & $\frac{5}{5}$ \\
\hline Regeneração & $140 \mathrm{Km}$ & 3 \\
\hline Batalha & $143 \mathrm{Km}$ & 3 \\
\hline Castelo do Piauí & $184 \mathrm{Km}$ & 3 \\
\hline Luzilăndia & $264 \mathrm{Km}$ & 3 \\
\hline Oeiras & $313 \mathrm{Km}$ & 3 \\
\hline Corrente & $874 \mathrm{Km}$ & 3 \\
\hline Lagoa do Piauí & $40 \mathrm{Km}$ & 2 \\
\hline Monsenhor Gil & $65 \mathrm{Km}$ & 2 \\
\hline Agricolăndia & $88 \mathrm{~km}$ & 2 \\
\hline Parnarama - MA & $\begin{array}{l}487 \mathrm{Km} \text { to São Luis } \\
90 \mathrm{Km} \text { to Teresina }\end{array}$ & 2 \\
\hline Agua Branca & $97 \mathrm{Km}$ & 2 \\
\hline Săo Gonçalo do Piauí & $101 \mathrm{Km}$ & 2 \\
\hline Coelho Neto-MA & $\begin{array}{l}385 \mathrm{Km} \text { to São Luis } \\
128 \mathrm{Km} \text { to Teresina }\end{array}$ & 2 \\
\hline Elesbão Veloso & $154 \mathrm{Km}$ & 2 \\
\hline Novo Oriente do Piauí & $178 \mathrm{Km}$ & 2 \\
\hline Esperantina & $180 \mathrm{Km}$ & 2 \\
\hline Francinópolis & $186 \mathrm{Km}$ & 2 \\
\hline Luis Correia & $365 \mathrm{Km}$ & 2 \\
\hline Canto do Buriti & $405 \mathrm{Km}$ & 2 \\
\hline São Raimundo Nonato & $536 \mathrm{Km}$ & $\frac{2}{2}$ \\
\hline Redençāo do Gurgueia & $700 \mathrm{Km}$ & 2 \\
\hline Altos & $38 \mathrm{Km}$ & 1 \\
\hline Coivaras & $40 \mathrm{Km}$ & 1 \\
\hline Curralinhos & $60 \mathrm{Km}$ & 1 \\
\hline Caxias - MA & $\begin{array}{l}360 \mathrm{Km} \text { to São Luis } \\
68 \mathrm{Km} \text { to Teresina }\end{array}$ & 1 \\
\hline Beneditinos & $91 \mathrm{Km}$ & 1 \\
\hline Passagem Franca do Piauí & $108 \mathrm{Km}$ & 1 \\
\hline Miguel Alves & $112 \mathrm{Km}$ & 1 \\
\hline Barras & $126 \mathrm{Km}$ & 1 \\
\hline
\end{tabular}

\begin{tabular}{|c|c|c|}
\hline City & Distance to capital & Number of victims \\
\hline Boqueiräo do Piaú & $136 \mathrm{Km}$ & 1 \\
\hline Amarante & $161 \mathrm{Km}$ & 1 \\
\hline Buriti (MA) & $\begin{array}{l}322 \mathrm{Km} \text { to São Luis } \\
176 \mathrm{Km} \text { to Teresina }\end{array}$ & 1 \\
\hline Santa Cruz dos Milagres & $180 \mathrm{~km}$ & 1 \\
\hline Săo Miguel do Tapuio & $190 \mathrm{Km}$ & 1 \\
\hline Piracuruca & $196 \mathrm{~km}$ & 1 \\
\hline São Joăo do Arraial & $203 \mathrm{Km}$ & 1 \\
\hline Valença do Piauí & $224 \mathrm{Km}$ & 1 \\
\hline Aroazes & $225 \mathrm{Km}$ & 1 \\
\hline Cocal & $226 \mathrm{Km}$ & 1 \\
\hline Matias Olímpio & $237 \mathrm{Km}$ & 1 \\
\hline Pimenteiras & $252 \mathrm{Km}$ & 1 \\
\hline São Bernardo (MA) & $\begin{array}{l}260 \mathrm{Km} \text { to Så Luis } \\
289 \mathrm{Km} \text { to Teresina }\end{array}$ & 1 \\
\hline Matões (MA) & $\begin{array}{l}143 \mathrm{Km} \text { to São Luis } \\
290 \mathrm{Km} \text { to Teresina }\end{array}$ & 1 \\
\hline Santana do Piauí & $303 \mathrm{Km}$ & 1 \\
\hline Magalhães de Almeida (MA) & $\begin{array}{l}409 \mathrm{Km} \text { to Sāo Luis } \\
323 \mathrm{Km} \text { to Teresina }\end{array}$ & 1 \\
\hline Itaveira & $350 \mathrm{Km}$ & 1 \\
\hline Săo João da Cana Brava & $350 \mathrm{~km}$ & 1 \\
\hline Alegrete do Piaui & $371 \mathrm{Km}$ & 1 \\
\hline Rio Grande do Piauí & $377 \mathrm{Km}$ & 1 \\
\hline Jaicós & $379 \mathrm{Km}$ & 1 \\
\hline Belém do Piauí & $383 \mathrm{Km}$ & 1 \\
\hline Vera Mendes & $386 \mathrm{~km}$ & 1 \\
\hline Capitão Gervásio Oliveira & $394 \mathrm{Km}$ & 1 \\
\hline Fronteiras & $406 \mathrm{Km}$ & 1 \\
\hline Simões & $427 \mathrm{Km}$ & 1 \\
\hline Pio IX & $444 \mathrm{Km}$ & 1 \\
\hline Santa Luz & $453 \mathrm{Km}$ & 1 \\
\hline Curral Novo do Piauí & $454 \mathrm{Km}$ & 1 \\
\hline Paes Landim & $457 \mathrm{Km}$ & 1 \\
\hline Barăo de Grajaú & $490 \mathrm{Km}$ & 1 \\
\hline Colónia do Gurgueia & $545 \mathrm{Km}$ & 1 \\
\hline Bom Jesus & $635 \mathrm{Km}$ & 1 \\
\hline Barreiras do Piauí & $760 \mathrm{Km}$ & 1 \\
\hline Curimatá & $775 \mathrm{Km}$ & 1 \\
\hline
\end{tabular}

Fig. 9 Distribution of the cities of origin of the motor vehicle collision victims treated at an emergency hospital in Teresina, in the state of Piauí, classified according to the distance from Teresina and the number of victims. 
and between 25 and 34 years old, with a total of $38.84 \%$. The analysis, which was conducted in Piauí as well, also found a predominant age group between 20 and 29 years old, with values always $>30 \%$. This study also describes similar data found in other countries, such as Australia, where the predominant age group of motor vehicle collision victims is between 18 and 25 years old. ${ }^{10,11}$

According to the Brazilian National Policy for the Reduction of Morbidity and Mortality due to Accidents and Violence, implemented by Administrative Decree GM/MS no. 737, from 05/16/2001, data from the Hospital Admission Authorizations (AIH, in the Portuguese acronym) showed a total of 679,511 admissions to hospitals linked to the Brazilian Unified Healthcare System (SUS, in the Portuguese acronym) in 1996. From those, most were male in the age group between 15 and 29 years old, and correlated, mainly, to traffic collisions. ${ }^{12}$

The economic impact of collisions and violence in Brazil can be directly measured by inpatient hospital expenses, including intensive care units, and days of general stay. In 1997, the total of these expenses corresponded to R\$ $232,376,612.16$, which represented $\sim 8 \%$ of the expenses with hospitalizations for all causes. ${ }^{12}$

In addition, the main group committed is the economically most active segment of the population: young men. ${ }^{2,12}$

This profile is due to the greater exposure of men and young people to traffic and the behavior that causes them to take greater risks when driving vehicles. Inexperience, thrillseeking, pleasure in experiencing sensations of risk, impulsivity and alcohol or drug abuse are factors that contribute to the higher incidence of traffic collisions in this group., ${ }^{8,13}$

Still characterizing the profile of motor vehicle collision victims, the present study observed a majority of brownskinned individuals (47\%), followed by white (24.5\%) and black (24\%). These data were different from those found in the study conducted in Tubarão, considering the different methodology, which classified 101 collision victims as white (71.3\%) and non-white individuals (28.7\%). It is important to emphasize that the aforementioned study was performed in a city where the majority of the population is of Caucasian origin. Some studies have shown that the level of blood alcohol and its consequent relation to the survival of TBI patients vary according to race/ethnicity. ${ }^{9,14,15}$

The profile of the victims found in the present study is based on data from the 2014 World Health Organization (WHO) report on alcohol and health, which analyzes a variety of factors identified for the consumption and risk of alcohol use disorders, such as economic development, culture, alcohol availability, and the level of policy effectiveness against alcohol consumption. ${ }^{4}$

These factors are relevant to explain differences in societal vulnerability, historical trends in alcohol consumption, and alcohol damage. Thus, adolescents are generally more vulnerable to early initiation into alcohol consumption and to the harmful effects of alcohol. ${ }^{4,16}$

Corroborating these data, Gaudêncio and Leão ${ }^{2}$ performed a literature review in 2013, with articles published between 2002 and 2011, and observed a predominance of male patients, with the most affected group aged between 21 and 60 years. In this analysis, they also found that more than $50 \%$ of the victims of traffic collisions who suffered TBI did not use personal protective equipment (PPE).

Similarly, Santos et al, ${ }^{11}$-in a research performed in an emergency service in Teresina (PI), which provides services to clients in the state itself, and in neighboring states such as Maranhão, Pará and Tocantins, found that $85.8 \%$ of the victims were aged between 15 and 34 years, and that $95 \%$ of them were motorcycle drivers. ${ }^{11}$

According to the WHO report on alcohol, men have a much higher rate of total disease burden expressed in incapacityadjusted life years attributable to alcohol than women, because, compared with women, men drink more and more often, and are less often abstainers.

Regarding the characteristics of the collision, the present study points to a greater probability of an motor vehicle collision during weekends, at night, and involving motorcycles.

These data were also found by a study that evaluated the characteristics of patients with head trauma treated at the Hospital das Clínicas of Faculdade de Medicina de Ribeirão Preto, in the state of São Paulo. In this study, the circadian distribution of hospital arrivals revealed a curve with lower frequency in the morning ( $5 \%$ ), which progressively increased until it reached a high plateau in the late afternoon and early evening (25-30\%), and subsequently fell until the morning. ${ }^{17}$

As for the day of the week, similar results were obtained in the aforementioned São Paulo study, in which the weekly distribution presented relatively constant daily treatments from Tuesday to Friday, increasing steadily at the end of the week, peaking and falling steadily until reaching basal levels on Tuesday.

Santos et $\mathrm{al}^{11}$ also verified in their study that $76 \%$ of the patients were victims of a motor vehicle collision from Thursday to Sunday, and that $52.3 \%$ of the collisions occurred at night. ${ }^{11}$

Still in this research, the authors observed that out of the 141 victims who reported having used alcohol, although without legal evidence, $57.4 \%$ of them did so during the night. They inferred, therefore, that the increase in the number of accidents in the aforementioned period is related to the increase in the ingestion of alcohol, with 3 times more chance of occurrence of collisions on weekends among those who had ingested alcohol. ${ }^{11}$

Regarding the means of locomotion, due to the shocking results found in several national studies, the traumas caused by motorcycle accidents deserve attention, especially the policies to control their occurrence and the planning of preventive actions. ${ }^{2,8,18-21}$

Therefore, it is necessary to implement campaigns with guidelines for motorcyclists and cyclists, emphasizing the risk situations to try to reduce the number of victims of trauma among the users of these means of transportation.

This concern is ratified by the number of motorcycles in Piauí, a state located in the Northeastern region of Brazil. According to a research conducted by the Brazilian Association of Motorcycle Manufacturers (Abraciclo, in the 
Portuguese acronym) between 1998 and 2012, the Northeast is in the second position among the regions of Brazil that showed the greatest increase in the circulating fleet of motorcycles, and Piauí ranks fourth among the states of the Northeast. The region presented a growth of $1,190.1 \%$ in the number of motorcycles circulating in the period. The survey was based on data released by the Brazilian National Traffic Department (Denatran, in the Portuguese acronym). ${ }^{12}$

In the present study, the majority (81\%) of the victims who presented to the emergency hospital came from other cities, ranging from cities close to the capital to cities from other states. This is important because the success in care regarding patients who are victims of motor vehicle collisions is time-dependent. In spite of this, the necessary advanced life support is not always present in cities far from the capital in the state of Piauí.

To ratify this unfavorable prognosis, studies have verified that associated disorders, such as cerebral swelling, result in the death of traffic collision victims before the first 24 hours of the crash, and that only $30.8 \%$ of the victims survived for one day or more. 22,23

Regarding the main neurological lesions presented by the patients, 45 of them presented DAI, and, of these, 11 had a record of alcoholic beverage ingestion. Considering the types of DAI, most had a mild to moderate degree (I and II) of injury. In a postmortem study with 120 fatalities at the Legal Medical Institute of the city of Belo Horizonte from 1989 to 1993, DAI was observed in $96(80 \%)$ of the brains examined, and it was classified as grade I in $21.9 \%$ (21), grade II in $51 \%$ (49), and grade III in $27.1 \%$ (26) of the patients, with the majority also having a mild to moderate degree of injury (I and II). 7,22

Proportionally, these data ratified the information contained in the guidelines for attention to the rehabilitation of the patient with TBI, according to which:

- $19 \%$ of DAIs are mild, characterized by coma after trauma in the initial 6 to 24 hours, with neuropsychological deficit with some degree of memory deficit, and $15 \%$ of cases evolving to death;

- $45 \%$ are moderate, characterized by coma for a period longer than 24 hours, with no sign of brain stem involvement, and mortality reaching $24 \%$ of patients; those who recover have some sequelae;

- 36\% are severe, with coma lasting longer than 24 hours, with signs of brain stem injury, and mortality in $51 \%$ of the cases. $^{24}$

In addition, the patient with head trauma is exposed to respiratory disorders, either due to nerve damage or aspiration of gastric contents when vomiting. Cranial infections resulting from solutions of continuity of the bandaging, thromboses due to vascular trauma, stress ulcers and neurogenic pulmonary edema can also occur. ${ }^{5,25}$

Thus, the prognosis of patients with TBI is quite poor, as previously observed based on a sample of 206 patients with severe TBI (score $\leq 8$ on the Glasgow coma scale [GCS]). The initial severity measured by the GCS, the presence of intracranial hypertension ( $>20 \mathrm{~mm} \mathrm{Hg}$ ), the type of intracranial lesion, and the presence of hypoxia, hypotension, and the association of hypoxia and hypotension had a significant influence on the progression of the patients. ${ }^{26}$

In view of the considerable morbidity and mortality caused by TBI and other injuries related to traffic collisions, traffic trauma is now considered a true public health problem in countries such as Brazil. Projections for 2020 point to traffic collisions as the third among the general causes of worldwide mortality. ${ }^{27}$

Therefore, epidemiological studies on this subject are essential for improvements in both pre- and in-hospital care, as well as in educational campaigns, which need to be more efficient in modifying this reality. ${ }^{20,21}$

\section{Conclusion}

The present study enabled the analysis of the epidemiological characteristics of the increasingly common victims of traffic collisions in Brazilian cities, the characterization of their behavior over time, and the knowledge of the most exposed groups, making it possible to highlight the need to implement prevention strategies that can reduce risks and their consequences.

There was a predominance of the motorcycle as the main vehicle involved in the collisions, with the prevalence of severe TBI, young age (economically active population), and male gender.

In spite of the limitations regarding the lack of statistical significance, mainly due to the lack of data in the registry files, it is believed that the present study was able to trace the profile of the victims studied, providing important information about the risk groups for traffic collisions that could offer subsidies for preventive and control actions in the state of Piauí.

In addition, there was a high demand from cities in the interior of the state, some of which were very distant from the capital, such as Corrente $(874 \mathrm{~km})$, determining a poor prognosis as it is a time-dependent condition for expert evaluation and choice of appropriate treatment (surgical, conservative, mechanical ventilation). Therefore, there is a need for specialized, decentralized treatment centers in macro-regions in the north and south of the state for a better care of trauma victims.

It is suggested that a study be performed to evaluate the degree of alcoholism, since the Commission of Jurists of the Senate approved, in April 2012, zero tolerance for those who drink and drive. The greater degree of severity of the lesions was demonstrated with the increase in blood alcohol levels, highlighting the need for greater efforts on the part of the authorities to implement measures of education in traffic, prevention and control.

\section{References}

1 Atendimento pré-hospitalar ao traumatizado, PHTLS/NAEMT, [Tradução Renata Scavone et al.]. 7th ed. Rio de Janeiro: Elsevier; 2011

2 Gaudêncio TG, Leão GM. The Epidemiology of Traumatic Brain Injury: A Bibliographical Survey In Brazil. Rev Neurocienc 2013; 21(03):427-434 
3 Fonoff ET, de Amorim RLO. Traumatismo crânioencefálico. In: Atualização Terapêutica de Prado, Ramos e Valle: urgências e emergências - 2012/13. 1st ed. São Paulo: Artes Médicas; 2012:130-139

4 World Health Organization (WHO). Global status report on alcohol and health. 2014 ed. Geneva, Switzerland: WHO Press; 2014

5 Ribas GC, Manreza LA. Traumatismo Cranioencefálico. In: Nitrini $\mathrm{R}$, Bacheschi LA. A Neurologia que todo médico deve saber. 2nd ed. São Paulo: Editora Atheneu; 2003:189-203

6 Mayer SA, Rowland LP. Traumatismo cranioencefálico. In: Umphred DA. Reabilitação Neurológica. 4th. ed. São Paulo: Manole; 2004: 348-361

7 Hortobágyi T, Al-Sarraj S. The Significance of Diffuse Axonal Injury: how to diagnose it and what does it tell us? ACNR 2008; $8(02): 16-18$

8 Santos AMR, Coelho MJ. Atendimento de cliente com traumatismo em um serviço de emergência de hospital do Piauí. Esc Anna Nery 2003;7(03):369-378

9 Trevisol DJ, Bohm RL, Vinholes DB. Epidemiological profile of patients victims of trafic accidents treated in the emergency room of Hospital Nossa Senhora da Conceição in Tubarão, Santa Catarina state, Brazil. Sci Med (Porto Alegre) 2012;22(03):148-152

10 Bastos YGL, Andrade SM, Soares DA. [Characteristics of traffic accidents and victims treated through a pre-hospital service in a city in southern Brazil, 1997/2000]. Cad Saude Publica 2005;21 (03):815-822

11 Santos AM, Moura ME, Nunes BM, Leal CF, Teles JB. [Profile of motorcycle accident victims treated at a public hospital emergency department]. Cad Saude Publica 2008;24(08):1927-1938

12 de Trânsito E. Departamento Nacional de Trânsito. Política Nacional de Redução da Morbimortalidade por Acidentes e Violências: Portaria MS/GM n ${ }^{\circ} 737$ de 16/5/01, publicada no DOU nº 96 seção 1e, de 18/5/ 01/ Ministério da Saúde. - Brasília: Ministério da Saúde; 2002

13 Andrade SM, Jorge MHM. [Characteristics of the victims of traffic accidents in a city of the southern region of Brazil]. Rev Saude Publica 2000;34(02):149-156

14 Linton KF, Kim BJ. The Moderation of blood alcohol levels on higher odds of survival among American Indians with violent, blunt-force traumatic brain injuries. Soc Work Public Health 2016;31(03):168-174

15 Bernier RA, Hillary FG. Trends in alcohol use during moderate and severe traumatic brain injury: 18 years of neurotrauma in Pennsylvania. Brain Inj 2016;30(04):414-421
16 Dewan G, Chowdhury FR. Alcohol Use and Alcohol Use Disorders in Bangladesh. Asia Pac J Med Toxicol 2015;4:83-90

17 Colli BO, Sato T, De Oliveira RS, et al. [Characteristics of the patients with head injury assisted at the Hospital das Clinicas of the Ribeirão Preto Medical School]. Arq Neuropsiquiatr 1997; 55(01):91-100

18 Canova JCM, Bueno MFR, Oliver CCD, et al. Cranioencephalic trauma of patients victims of motorcycle accidents. Arq Ciênc Saúde 2010;17:9-14

19 Brito NMG, Coelho KWS, Alencar AMPG, Pinho FVSA, Carvalho ZMF. Caracterização de pacientes com trauma crânio encefálico (TCE) por acidente motociclístico em um hospital de Barbalha - Ceará. In: Congresso Brasileiro de Enfermagem, 61, 2009, Fortaleza. 61 ${ }^{\circ}$ Congresso Brasileiro de Enfermagem. Fortaleza: ABEN- Ce, 2009, 478-481

20 Ribeiro AACR. Caracterização do perfil das vítimas de acidente de trânsito com motocicleta, na área de abrangência no PSF Boa Esperança, no município de Alfenas/MG. [monografia]. Campos Gerais: Universidade Federal de Minas Gerais. Campos Gerais Minas Gerais; 2010

21 Ganne N, Martinez AT, Rodrigues C, Delgado MHC, Souza FA. Motorcycle accidents in the Municipality of Corumbá, Mato Grosso doSul State, Brazil, in 2010. Rev. Pan-Amaz Saúde 2013;4(01):15-22

22 Pittella JEH, Gusmão SNS. The conformation of the brain plays an important role in the distribution of diffuse axonal injury in fatal road traffic accident. Arq Neuropsiquiatr 2004;62(2B):406-412

23 Gusmão SS, Pittella JEH. [Congestive brain swelling in victims of fatal road accident. Frequency and association with other head injury lesions]. Arq Neuropsiquiatr 1999;57(04):965-970

24 Ministério da Saúde. Secretaria de Atenção à Saúde. Diretrizes de atenção à reabilitação da pessoa com traumatismo cranioencefálico / Ministério da Saúde. Secretaria de Atenção à Saúde. Departamento de Ações Programáticas Estratégicas. Brasília: Ministério da Saúde; 2015

25 Melo JRT, Oliveira Filho J, da Silva RA, Moreira Júnior ED. [Prognostic factors about morbidity and lethality in head injury]. Arq Neuropsiquiatr 2005;63(04):1054-1057

26 Dantas Filho VP, Falcão AL, Sardinha LA, Facure JJ, Araújo S, Terzi RG. [Relevant factors influencing the evolution of 206 patients with severe head injury]. Arq Neuropsiquiatr 2004;62(2A):313-318

27 Abreu ÂMM, de Lima JM, Matos LN, Pillon SC. [Alcohol use and traffic accidents: a study of alcohol levels]. Rev Lat Am Enfermagem 2010;18(Spec No):513-520 